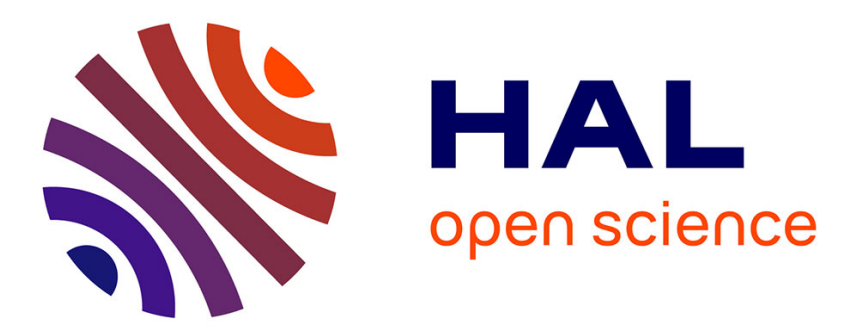

\title{
Nectar and pollen sugars constituting larval provisions of the alfalfa leaf-cutting bee (Megachile rotundata) (Hymenoptera: Apiformes: Megachilidae)
}

\author{
James Cane, Dale Gardner, Philip Harrison
}

\section{- To cite this version:}

James Cane, Dale Gardner, Philip Harrison. Nectar and pollen sugars constituting larval provisions of the alfalfa leaf-cutting bee (Megachile rotundata) (Hymenoptera: Apiformes: Megachilidae). Apidologie, 2011, 42 (3), pp.401-408. 10.1007/s13592-011-0005-0 . hal-01003584

\section{HAL Id: hal-01003584 \\ https://hal.science/hal-01003584}

Submitted on 1 Jan 2011

HAL is a multi-disciplinary open access archive for the deposit and dissemination of scientific research documents, whether they are published or not. The documents may come from teaching and research institutions in France or abroad, or from public or private research centers.
L'archive ouverte pluridisciplinaire HAL, est destinée au dépôt et à la diffusion de documents scientifiques de niveau recherche, publiés ou non, émanant des établissements d'enseignement et de recherche français ou étrangers, des laboratoires publics ou privés. 


\title{
Nectar and pollen sugars constituting larval provisions of the alfalfa leaf-cutting bee (Megachile rotundata) (Hymenoptera: Apiformes: Megachilidae)
}

\author{
James H. CANe ${ }^{1}$, Dale R. GARdner ${ }^{2}$, Philip A. Harrison ${ }^{3}$ \\ ${ }^{1}$ USDA-ARS Bee Biology and Systematic Laboratory, Utah State University, Logan, UT 84322, USA \\ ${ }^{2}$ USDA-ARS Poisonous Plant Research Laboratory, Utah State University, Logan, UT 84341, USA \\ ${ }^{3}$ USDA-ARS Forage and Range Research Laboratory, Utah State University, Logan, UT 84322, USA
}

Received 19 February 2010 - Revised 02 July 2010 - Accepted 2 July 2010

\begin{abstract}
As with most solitary bees, larvae of the alfalfa leaf-cutting bee, Megachile rotundata Fab., eat a diet blended from pollen and nectar of unknown proportions. In this study, we developed protocols to isolate and quantify sugars from larval provision masses. The method removed free amino acids that leach from pollen and confound chromatography, but without autohydrolyzing sucrose. Pollen sugars were a negligible fraction of provision mass sugars. Glucose and fructose constituted about half of the provision fresh weight. Sucrose in alfalfa pollen and nectar is absent from the provision, presumably enzymatically hydrolyzed to glucose and fructose in the provision. Provision masses are composed of two to three times more floral equivalents in pollen than nectar. Female M. rotundata, and other solitary bees with pasty provisions, gather proportionally more pollen than nectar compared with the resource needs of colonies of social honeybees and bumblebees.
\end{abstract}

HPLC / Medicago / pollinator / Apoidea / diet

\section{INTRODUCTION}

Bee larvae receive diets of pollen and nectar, in some cases fortified with floral oils or adult glandular secretions (Roubik 1989). In the case of the solitary (non-social) species - which constitute most of the world's bee fauna-the mother bee mixes pollen with sufficient nectar to form a provision mass containing all of the nutrients needed to produce one offspring. The consistencies of larval provision masses range from soupy liquids to firm doughy balls, depending on the species (or genus) of bee (Malyshev 1935; Stephen et al. 1969; Bosch et al. 2001). A given bee species' provision masses appear

Corresponding author: J.H. Cane,

Jim.Cane@ars.usda.gov

Manuscript editor: Klaus Hartfelder similar in consistency, but we have not had analytical means to reliably characterize the specific proportions of nectar and pollen that constitute larval provision masses.

Nectar is the obvious source of sugars in a larval bee's diet, but pollen also contains simple soluble sugars (Pacini 1996). Sucrose is the most common sugar in pollen, constituting 2$20 \%$ of pollen grain weight (Speranza et al. 1997). The quantity and fate of this pollen sugar in larval bee provisions is unknown. If pollen sugar contributes significantly to the total sugar content of a provision mass, then it could change our estimates for nectar provisioning needs by foraging mother bees.

Analysis of sugars in larval bee diets is complicated by other aqueous leachates from pollen, notably the free amino acids. These are frequent and diverse in pollen (Solberg 
and Remedios 1980, reviewed in Roulston and Cane 2000). For instance, Petunia pollen immersed in aqueous media released $50-80 \%$ of its content of amino acids in a few minutes (Linskens and Schrauwen 1969). In that study, proline was the predominant amino acid, which constituted $2.6 \%$ of Petunia pollen weight (Linskens and Schrauwen 1969). Proline often predominates in other pollen species (reviewed in Roulston and Cane 2000). Unfortunately, during typical sugar analyses by high-performance liquid chromatography (HPLC) ion chromatography (IC-IPAD), proline co-elutes with fructose and glutamine interferes with the detector response to glucose (Eggleston 1999), these being the two monosaccharides prevalent in nectar. Thus, amino acids leached from pollen can confound both detection and quantification of nectar sugars in the provision masses of larval solitary bees (or stored pollen of social species). To reliably analyze sugar contents of either pure pollen or larval provision masses, these amino acids must be effectively removed first without inadvertently altering the extracted sugars, especially by acid hydrolysis ("inversion") of sucrose to its constituent monosaccharides (Eggleston 1999). Some chromatography and filtering substrates can cause this hydrolysis, even some weak cation exchange resins (Eggleston 1999).

The objectives of this study were to: (1) characterize and quantify pollen, water and sugar in larval provision masses of a nonsocial bee, and (2) evaluate the constitution and origins of the soluble sugars from the nectar and pollen that the mother bee combines in the larval provision mass. Several reasons guided our choice of the managed pollinator, Megachile rotundata Fab. for this study. First, as the primary pollinator of seed alfalfa (Medicago sativa L., Fabaceae) in North America, it is the world's most agriculturally valuable non-social bee. For this reason, it has also been more extensively studied than other non-social bees (Pitts-Singer 2008). Taxonomic purity of its provisions is assured when these females forage amid sizeable fields of bloom- ing alfalfa monocultures. Being a cavity-nester, we could readily access their fresh, newlyprovisioned nest cells; not only do groundnesting bees present nest excavation challenges, but their provisions (or larvae) can apparently acquire substantial moisture from the soil atmosphere (May 1972) that would confound our estimates of nectar water in provisions. For all these reason, this study focuses on provision sugars of the bee $M$. rotundata.

\section{MATERIALS AND METHODS}

\subsection{Sampling methods}

Pollen, nectar, and nest provision samples came from a region of commercial alfalfa seed fields (Forage Genetics cultivar 'FM-4 M73') west of Walla Walla, Washington (Cane 2008) during late June 2001. Fresh alfalfa pollen was obtained from 30 female $M$. rotundata bees caught and killed as they returned to their nests. Groups of five females with full, dry pollen loads were manually stripped of pollen. Fresh pollen in pooled samples was weighed and, after extraction for sugars (detailed below), counted using an automated particle counter (HIAC/ ROYCO; method in Cane et al. 1996). Subsets of samples were recounted, and differences assessed by paired $t$ test to evaluate counting accuracy.

To collect nectar, budded racemes of alfalfa were enclosed in fine mesh bags 2-4 days prior to collection. This allowed nectar to accumulate in the absence of bee visitors. Two samples were pooled from younger flowers (1-2 days), two from older (23 days), and one mixed; all estimated from their position on the flowering raceme. Centrifuge extraction of floral nectar (Holtkamp et al. 1992; Barnes and Furgala 1978) was attempted but not pursued, as we found that centrifugation of just floral buds also yielded a liquid with a refractive index. Instead, we extracted nectar directly from the small individual flowers. Flowers were viewed at $\times 100$ magnification after first clipping away the banner petal to reveal the basal nectaries. Visible droplet(s) of nectar then were drawn up into a microcapillary pipette (Drummond Inc.). The length of the column of liquid was measured to the nearest $0.5 \mathrm{~mm}$ using calipers for 
calculating volumes. Five pooled samples were accumulated from 10 to 38 flowers each. All samples were frozen for storage and then thawed just prior to analysis.

Female $M$. rotundata were induced to nest in packs of grooved wooden boards that we placed within large active nesting shelters amid the same commercial alfalfa seed fields at peak bloom in late June 2001. Newly completed nest cells were daily removed. Each fresh provision mass (minus the bee's egg) was scraped free from its leafy nest cell lining as completely as possible and frozen for analysis. Samples contaminated with tiny leaf fragments were pressed through a fine sieve.

\subsection{Extraction and analysis}

Each of 70 thawed provisions was weighed, cut in half lengthwise, and each half reweighed. One half of each provision was then oven-dried at $65^{\circ} \mathrm{C}$ for $36 \mathrm{~h}$ and weighed again to estimate moisture content. The other half was placed in $1.0 \mathrm{~mL}$ water (always HPLC grade) at $25^{\circ} \mathrm{C}$, dispersed by vortex mixer for $1 \mathrm{~min}$, and after standing for $10 \mathrm{~min}$ to leach and settle, centrifuged for $20 \mathrm{~s}$. Pollen in the resulting pellet was counted as above. Pooled pure pollen samples from bees were handled identically, except that the original extraction was in $0.5 \mathrm{~mL}$ water. To remove any interfering amino acids and lipids from pollen, $0.1 \mathrm{~mL}$ aliquots of the supernatant were added to non-polar $\mathrm{C}_{18}$ SPE columns (J.T. Baker) mounted on a vacuum manifold. SPE columns were preconditioned with $1 \mathrm{~mL}$ water. Individual samples of the aqueous sugars were eluted from a SPE column by the addition of two $0.5 \mathrm{~mL}$ aliquots of water. Each thawed pooled sample of floral nectar was simply diluted in $1 \mathrm{~mL}$ of water before HPLC analysis.

The aqueous sugar extracts were analyzed by HPLC (HP1090 series II) and detected using a refractive index detector (HP1047A) and recording integrator (HP3396 series II). The $300 \times 6.5 \mathrm{~mm}$ column was packed with a sulfonated polystyrene cation exchange resin (carbohydrate column, Alltech Assoc. Inc., Deerfield, IL, USA), preceded by a guard column of the same phase. The mobile phase was filtered, deionized water (17 $\mathrm{M} \Omega$ ) sparged with helium to remove carbonate and displace air. Flow rate was $0.5 \mathrm{~mL} / \mathrm{min}$. The column oven was run isothermally at $90^{\circ} \mathrm{C}$, the detector at $40^{\circ} \mathrm{C}$. Run time was set to $15 \mathrm{~min}$, after confirming that no later peaks resulted after pollen and nectar extracts were run for $50 \mathrm{~min}$. Injected volumes were $20 \mu \mathrm{L}$ for pollen and provisions, $10 \mu \mathrm{L}$ for nectar. A composite sugar standard (500 ppm sucrose, fructose, and glucose dissolved in filtered, deionized water) was blended, subdivided and frozen. Aliquots $(20 \mu \mathrm{L})$ from this standard were interspersed between every fifth sample to confirm retention times and peak areas.

Tentative sugar identities were assigned by matched retention times and co-elution with sucrose, glucose, and fructose, each of which was fully resolved from neighboring peaks. Sugar identities were confirmed by co-elution with water-soluble sugar standards (seven mono- and disaccharides, fructans) using a Dionex DX 500 ion chromatograph equipped with a PAD detector (Sunnyvale, CA, USA) and a PA-100 carbohydrate column run at a flow rate of $1.0 \mathrm{~mL} / \mathrm{min}$. Carbohydrates were eluted with a sodium acetate gradient $(25-100 \mathrm{mM})$ in $150 \mathrm{mM}$ $\mathrm{NaOH}$.

The fraction of a provision that was sugar was regressed on fresh provision weight. Throughout, data is reported as the mean \pm 1 standard deviation.

\section{RESULTS}

Pollen leachates and nectar both contained sucrose and fructose; nectar additionally contained detectable glucose (Table I). No other mono- or disaccharides were detected. A single unknown compound, found only in extracts of the provision masses, was detected with both HPLCs. It was always present, averaged $13 \%$ of the total chromatogram area. Compared with a standard of naturally-occurring soluble mono-, di-, and trisaccharides, it co-eluted with 1kestose on the Dionex column but not the Alltech column. No detectable loss or transformation of sucrose was caused by processing the sugar standard through a $\mathrm{C}_{18}$ SPE column (quantities within $0.5 \%$ of original standard). Integrator peak area regressed linearly with sugar concentrations for a 200-fold dilution series of the three sugar standard $\left(r^{2}>0.99\right)$. This bracketed the range of concentrations of 
Table I. Quantities of the three soluble sugars present in alfalfa nectar and pollen, and in larval provisions of the bee $M$. rotundata.

\begin{tabular}{lccccc}
\hline & & \multicolumn{2}{l}{ Soluble sugars $(\mu \mathrm{g})$} & \\
\cline { 3 - 5 } Source & Unit & Sucrose & Glucose & Fructose & Total $(\mu \mathrm{g})$ \\
\hline Pollen & Flower & $0.52 \pm 0.21$ & - & $0.09 \pm 0.11$ & $0.63 \pm 0.26$ \\
& 1 Million grains & $157 \pm 63$ & - & $26 \pm 32$ & $188 \pm 79$ \\
Nectar & Flower & $136 \pm 178$ & $101 \pm 112$ & $105 \pm 109$ & $342 \pm 398$ \\
& $1 \mu \mathrm{L}$ & $427 \pm 452$ & $315 \pm 276$ & $328 \pm 268$ & $1070 \pm 986$ \\
Larval bee & $1 \mathrm{mg}$ of fresh provision mass & - & $138 \pm 30$ & $223 \pm 47$ & $361 \pm 70$ \\
Provisions & & & & &
\end{tabular}

our samples, allowing interpolation of concentrations for each sample analyzed. Peak areas of repeat runs of the sugar standard were closely similar (coefficients of variation $=0.4-1.6 \%$ ).

Individual alfalfa flowers produced an average of $3,326 \pm 845$ pollen grains. Flowers varied widely in nectar volume $(0-1.7 \mu \mathrm{L})$, but averaged $0.29 \pm 0.24 \mu \mathrm{L}$. Pooled samples of pollen taken from five returning bees averaged $470,000 \pm 46,000$ grains (or 117,000 grains per bee). Recounts of grains in these pollen samples differed only $4 \%$ on average, which was statistically insignificant (paired $t_{[15]}=0.8, P>$ 0.4 ). Fresh provision masses averaged $90 \pm$ $26 \mathrm{mg}$ (median $88 \mathrm{mg}$ ) in weight and contained 1.3 million pollen grains. Nearly half of a provision's weight $(42 \mathrm{mg})$ is attributable to sugar, nearly all of it coming from nectar (Figure 1). Sugar and pollen constitution of provisions varied more than water content (Figure 2), but that could reflect variability introduced by the more complex analytical methods required of pollen and sugar. The proportion of sugar in a provision regressed positively on its overall size $(P \leq 0.05)$ but only explained $4 \%$ of the variation in sugar content.

\section{DISCUSSION}

The prevalent sugar in alfalfa pollen was sucrose (Table I), as has been reported for pollen of representatives of a few other plant families (Speranza et al. 1997). There is also precedent for smaller quantities of fructose in pollen from bee-pollinated flowers, but usually it is matched in concentration by glucose, which we did not detect in alfalfa pollen. Sugars from alfalfa pollen contribute negligibly to the total soluble sugars present in larval diets of $M$. rotundata (Table I, Figure 1).

Alfalfa nectar volumes were small and variable. Alfalfa nectar consistently contained nearly equal proportions of sucrose, glucose, and fructose; no other sugars were detected (Table I). These three sugars, and the absence of other soluble sugars, confirm earlier alfalfa nectar studies (Holtkamp et al. 1992; Speranza et al. 1997; Barnes and Furgala 1978). Holtkamp et al (1992) reported lesser but comparable concentrations of glucose and fructose (6-40

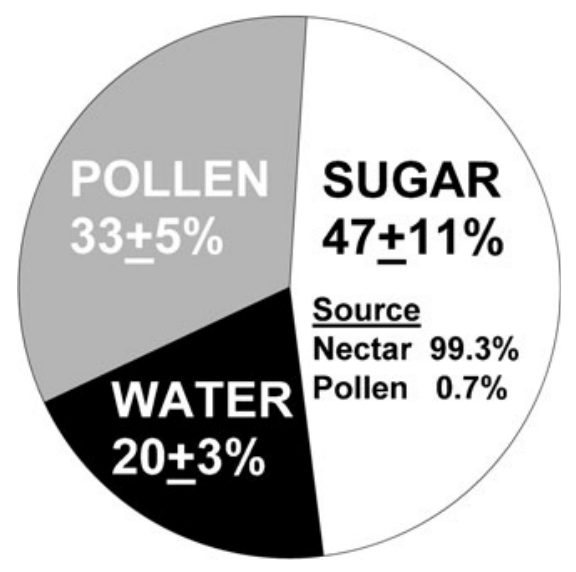

Figure 1. Average provision constitution and floral sources of sugars in larval provisions of the bee $M$. rotundata. 


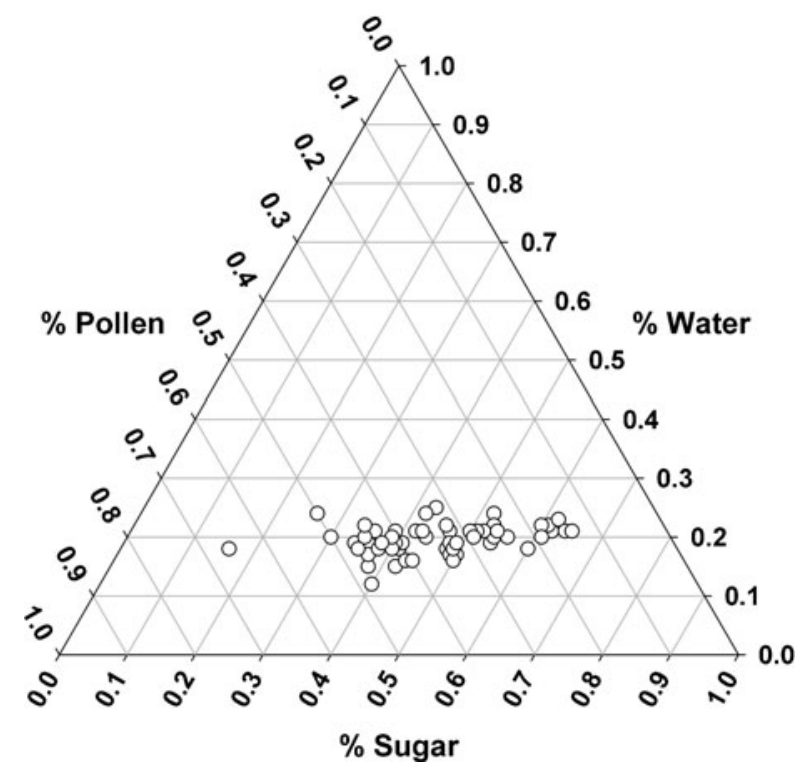

Figure 2. Variation in the relative proportions of pollen, water and sugar constituting individual provision masses of $M$. rotundata.

vs. $31-33 \mathrm{~g} / 100 \mathrm{~mL})$. In that study, sucrose concentrations were found to vary considerably among cultivars, up to $80 \%$ of glucose or fructose concentrations. We found the sucrose concentration of alfalfa nectar to slightly exceed that of either monosaccharide (Table I), possibly owing to additional varietal selection, lack of inadvertent hydrolysis of sucrose during processing compared with the earlier studies, or some error of our own.

For larval provision masses of $M$. rotundata, our estimate of average constitution is remarkably similar to an earlier study despite entirely different means of measurement. Klostermeyer et al. (1973) used clever gravimetric methods to measure incremental gains in nest weights as they were gradually provisioned by six female $M$. rotundata with pollen and nectar of sweet clover (Melilotus spp., Fabaceae). They reported that fresh provisions consisted of $36 \%$ sweet clover pollen and $64 \%$ nectar by weight. Provisions that we analyzed chemically were found to contain on average $33 \%$ alfalfa pollen and $67 \%$ of its nectar by weight $(20 \%$ water plus 47\% sugar; Figure 1). An earlier HPLC analysis of $M$. rotundata larval provision masses, which did not first remove free amino acids, reported $4-5 \%$ more sugar per unit dry weight of alfalfa provision than found here (Inglis et al. 1992).

Larval provisions of $M$. rotundata contained only fructose and glucose; the sucrose that was present in both the nectar and pollen of alfalfa flowers was absent from the bees' provisions. Inglis et al. (1992) reported only a trace of sucrose $(1.7 \%$ of the sugar fraction) in $M$. rotundata provisions. The disaccharide's disappearance was likely due to hydrolysis into glucose and fructose, but how? Acid degradation or autohydrolysis of sucrose can occur in the presence of even mild acids or in contact with strong cation exchange resins (Eggleston 1999), but we found that our sucrose standard was unaltered and undiminished by our use of $\mathrm{C}_{18}$ SPE columns to first eliminate free amino acids from provision extracts. Invertase ( $=$ sucrase) in pollen reportedly fails to leach out in solution to hydrolyse exogenous sucrose (Echigo et al. 1973). However, later work with lily pollen showed its pollen to contain two invertase enzymes. One fraction is indeed bound to the cell wall, but the other is cytoplasmic, soluble, 
and capable of hydrolyzing sucrose in solution (Singh and Knox 1984). Sucrose persisted overnight without hydrolysis in our analyses of alfalfa pollen leachates, but that may have been an artifact of our extraction conditions.

Because sucrose was absent from larval provisions, we infer that sucrose in alfalfa nectar was likely hydrolyzed in the provision by an invertase enzyme either from the pollen itself or introduced by the mother bee. Invertase enzymes are used exogenously by some social bees, such as the European honeybee (Simpson et al. 1968) and some stingless bees (Vit and Pulcini 1996), in the process of producing honey from nectar. It may be that adult solitary bees also supply invertase to hydrolyze nectar sucrose in their progenies' diets, yet another aspect of parental care in these non-social taxa.

Alfalfa produces rewards in a ratio different from the bee's needs. Thus, calculating from our data, a provision consists of the amount nectar accumulated in 123 alfalfa flowers and the amount of pollen shed by 390 alfalfa flowers. This calculation, in floral equivalents, certainly must underestimate true foraging effort. It does not account for nectar removed by competing bees, particularly honey bees, which take nectar without tripping flowers (Cane 2002). Furthermore, foragers undoubtedly leave some pollen at flowers and some more is visibly lost when a bee trips a flower. From literature values for foraging and provisioning tempos (Klostermeyer and Gerber 1969; Gerber and Klostermeyer 1972), a maximum of 2,000 alfalfa flowers may need to be visited to provision a single nest cell (females visited eight flowers per min, and on average were away from the nest for $15 \mathrm{~min}$ during each of 17 trips to provision one nest cell). Inefficiencies in pollen acquisition will tend to further skew the 3:1 disparity between pollen and nectar production on the one hand and the proportions needed to assemble a larval provision on the other; pollen appears to be the limiting resource absent substantial nectar competition in alfalfa.

Our study, as well as the sweet cloverprovisioning study (Klostermeyer et al. 1973) suggest that female $M$. rotundata can assemble larval provisions that are consistent in both the ratio of pollen to nectar as well as overall provision weight despite their use of different floral hosts. Provisioning with the proper quantities of nectar and pollen seems critical for their reproductive success. Larval M. rotundata are remarkable for their high energy and nitrogen conversion efficiencies, while also wasting very little of their provision (ca. 2\%; Wightman and Rogers 1978). Mother bees tailor provision mass size to the sex of offspring (Klostermeyer et al. 1973); underfed daughters are smaller and often expire during winter diapause, a likely result of inadequate fat reserves (Pitts-Singer and Bosch 2010). The balance and quantity of nectar in provisions also may be important to their reproductive success. Egg and early instar larval mortality (so-called "pollen ball") yields 20-50\% juvenile mortality for managed $M$. rotundata, although the causes remain mysterious (Pitts-Singer 2004). Young larvae can only imbibe liquid from their provision (Trostle and Torchio 1994); drier provisions would impede this, and has been suspected as one cause of larvae dying on uneaten provisions (Pitts-Singer 2004; Bosch and Kemp 2005). Conversely, larvae risk drowning in overly wet provisions made from disproportionately too much nectar. By experimental manipulations of provisions, it should be possible to derive the range in quantities and ratios of pollen to nectar in provisions that is tolerated by young $M$. rotundata, and so the contribution inadequate nectar to overwintering mortality and "pollen ball" that reflects juvenile mortality in this and other bees.

The ratio of pollen to nectar in larval provisions of $M$. rotundata contrasts with that of colony needs among social bees (honeybees and bumblebees). The $20 \%$ moisture content of fresh $M$. rotundata larval provisions from eastern Washington state is very similar to the moisture content reported for incoming pollen pellets $(22 \%)$ and stored "bee bread" (19-21\%) taken from hived honeybee colonies in comparably arid Arizona and Wyoming (Herbert and Shimanuki 1978). For both kinds of bees, the moisture comes primarily from the nectar added by the female bee. However, social bee 
colonies should require a proportionately greater influx of dietary nectar overall for several additional uses such as wax synthesis, nest thermoregulation, and survival during seasons of dearth. At mid-latitude, the average feral colony of honeybees annually consumes an estimated $20 \mathrm{~kg}$ of pollen and $60 \mathrm{~kg}$ of honey (Seeley 1995). The honey represents $120 \mathrm{~kg}$ of nectar at the average value of $40 \%$ dissolved solids. A large mature colony of Bombus vosnesenskii daily consumes an estimated $25 \mathrm{~g}$ of pollen and $54 \mathrm{~g}$ of their honey, or $110 \mathrm{~g}$ of nectar (Heinrich 1979). Thus, the ratio of nectar to pollen consumption by colonies of these social bees is $6: 1$ and $4.5: 1$, respectively. In contrast, $M$. rotundata larval provisions consist of nectar and pollen in a 2:1 ratio (Figure 1). This solitary bee's nest provisions are thus half as sweet or twice as rich in pollen as the diet consumed by a social bee colony. This difference with social bees in the relative importance of pollen versus nectar should have implications for their individual foraging decisions, floral preferences, provisioning efforts, and floral resource competition with other bees.

\section{ACKNOWLEDGMENTS}

We are grateful to Don Veirs for able assistance in acquiring and processing alfalfa nectar and larval provisions, to Faye Rutishauser for help with particle counting, and to Terry Wierenga for guidance with HPLC. Theresa Pitts-Singer and John Neff provided thoughtful reviews. Research was funded by the Pacific Northwest Alfalfa Seed Growers Association.

Sucres du nectar et du pollen contenus dans les provisions destinées à l'alimentation des larves chez Megachile rotundata (Hymenoptera: Apiformes: Megachilidae).

HPLC / Medicago / pollinisateur / régime alimentaire / luzerne / Apoidea

Zusammenfassung - Nektar- und Pollenzucker als Komponenten des Larvenfutters der Blattschnei- derbiene Megachile rotundata (Hymenoptera: Apiformes: Megachilidae). Wie bei den meisten solitären Bienen erhalten auch die Larven der Blattschneiderbiene Megachile rotundata Fab. eine Diät bestehend aus einer Mischung nicht genau bekannter Anteile von Pollen und Nektar. In der vorliegenden Studie entwickelten wir ein Verfahren zur Isolierung und Quantifizierung der Zucker im Larvenfuttter. Die Methode entfernt aus Pollen herausgelöste freie Aminosäuren, die in der Chromatographie stören können., ohne dass es zur Autohydrolyse von Zuckern kommt. Während Pollenzucker nur einen geringen Anteil der Zuckerfraktion im Larvenfutter von $M$. rotundata ausmachten, waren Glukose und Fruktose zu etwa 50\% im Frischgewicht der Futtermenge vertreten. Sacharose, die in Alfalfapollen und Nektar vorkommt, war im Larvenfutter nicht zu finden, da sie vermutlich bei der Futteraufbereitung enzymatisch in Glukose und Fruktose gespalten wird. Im Vergleich zu Arbeiterinnen der sozialen Honigbienen und Hummeln sammeln Weibchen von $M$. rotundata, wie auch die anderer solitärer Bienen, die ihre Brut mit einem pastenartigen Brei füttern, proportional mehr Pollen als Nektar von den Futterpflanzen ein. Der flüssige Anteil im Futterbrei garantiert die Verpflegung der ersten drei Larvenstadien der Blattschneiderbienen, während ein zu trockener Futterbrei mit einer erhöhten Larvenmortalität verbunden ist.

\section{HPLC / Medicago / Bestäuber / Apoidea / Diät}

\section{REFERENCES}

Barnes, D.K., Furgala, B. (1978) Nectar characteristics associated with sources of alfalfa germplasm. Crop Sci. 18, 1087-1089

Bosch, J., Kemp, W.P. (2005) Alfalfa leafcutting bee population dynamics, flower availability, and pollination rates in two Oregon alfalfa fields. J. Econ. Entomol. 98, 1077-1086

Bosch, J., Maeta, Y., Rust, R. (2001) A phylogenetic analysis of nesting behavior in the genus Osmia (Hymenoptera: Megachilidae). Ann. Entomol. Soc. Am. 94, 617-627

Cane, J.H. (2002) Pollinating bees (Hymenoptera: Apiformes) of US alfalfa compared for rates of pod and seed set. J. Econ. Entomol. 95, 22-27

Cane, J.H. (2008) A native ground-nesting bee (Nomia melanderi) sustainably managed to pollinate alfalfa across an intensively agricultural landscape. Apidologie. 39, 315-323 
Cane, J.H., Schiffhauer, D., Kervin, L.J. (1996) Pollination, foraging, and nesting ecology of the leafcutting bee Megachile (Delomegachile) addenda (Hymenoptera: Megachilidae) on cranberry beds. Ann. Entomol. Soc. Am. 89, 361-367

Echigo, T., Takenaka, T., Ichimira, M. (1973) Effects of chemical constituents in pollen on the process of honey formation. Bull. Fac. Agric. Tamagawa Univ. 13, 1-9

Eggleston, G. (1999) Improved quantitative ion chromatography of industrial sugars: removal of interfering amino acids. Food Chem. 65, 483-491

Gerber, H.S., Klostermeyer, E.C. (1972) Factors affecting the sex ratio and nesting behavior of the alfalfa leafcutter bee. Washington Agric. Exper. Station Tech. Bull. 73, 1-11

Heinrich, B. (1979) Bumblebee economics. Harvard University Press, Cambridge

Herbert Jr., E.W., Shimanuki, H. (1978) Chemical composition and nutritive value of bee-collected and bee-stored pollen. Apidologie 9, 33-40

Holtkamp, R.H., Morthorpe, K.J., Clift, A.D. (1992) Influence of nectar volume and sugar content on seed set in lucerne. Australian J. Exp. Agric. 32, 713-716

Inglis, G.D., Goettel, M.S., Sigler, L. (1992) Analysis of alfalfa leafcutter bee (Megachile rotundata) provisions pre- and post-sterilization with propylene oxide. Apidologie 23, 119-132

Klostermeyer, E.C., Gerber, H.S. (1969) Nesting behavior of Megachile rotundata (Hymenoptera: Megachilidae) monitored with an event recorder. Ann. Entomol. Soc. Am. 62, 1321-1326

Klostermeyer, E.C., Mech Jr., S.J., Rasmussen, W.B. (1973) Sex and weight of Megachile rotundata (Hymenoptera: Megachilidae) progeny associated with provision weights. J. Kansas Entomol. Soc. 46, 536-548

Linskens, H.F., Schrauwen, J. (1969) The release of free amino acids from germinating pollen. Acta. Bot. Neerl. 18, 605-614

Malyshev, S.I. (1935) The nesting habits of solitary bees: a comparative study. EOS (Madrid) Rev. Espanola Entomol. 11, 201-309

May, D.G.K. (1972) Water uptake during larval development of a sweat bee, Augochlora pura (Hymenoptera: Apoidea). J. Kansas Entomol. Soc. 45, 439-449

Pacini, E. (1996) Types and meaning of pollen carbohydrate reserves. Sex Plant Reprod. 9, 362-366
Pitts-Singer, T.L. (2004) Examination of 'pollen balls' in nests of the alfalfa leafcutting bee, Megachile rotundata. J. Apic. Res. 43, 40-46

Pitts-Singer, T.L. (2008) Past and present management of alfalfa bees. In: James, R.R., Pitts-Singer, T.L. (eds.) Bees in agricultural ecosystems, pp. 105-123. Oxford University Press, NY

Pitts-Singer, T.L., Bosch, J. (2010) Nest establishment, pollination efficiency, and reproductive success of Megachile rotundata (Hymenoptera: Megachilidae) in relation to resource availability in field enclosures. Environ. Entomol. 39, 149-158

Roubik, D.W. (1989) Ecology and natural history of tropical bees. Cambridge University Press, Cambridge

Roulston, T.H., Cane, J.H. (2000) Pollen nutritional content and digestibility for animals. Plant Syst. Evol. 222, 187-209

Seeley, T.D. (1995) The wisdom of the hive. Harvard University Press, Cambridge

Simpson, J., Riedel, I.B.M., Wilding, N. (1968) Invertase in the hypopharyngeal glands of the honeybee. J. Apic. Res. 7, 29-36

Singh, M.B., Knox, B. (1984) Invertases of Lilium pollen. 1.Characterization and activity during in vitro germination. Plant Physiol. 74, 510-515

Solberg, Y., Remedios, G. (1980) Chemical composition of pure and bee-collected pollen. Sci. Rep. Agric. Univ. Norway. 59, 1-12

Speranza, A., Calzoni, G.L., Pacini, E. (1997) Occurrence of mono- or disaccharides and polysaccharide reserves in mature pollen grains. Sex Plant Reprod. 10, 110-115

Stephen, W.P., Bohart, G.E., Torchio, P.F. (1969) The biology and external morphology of bees. Agric. Exp. Sta. Oregon St. Univ, Corvallis

Trostle, G., Torchio, P.F. (1994) Comparative nesting behavior and immature development of Megachile rotundata (Fabricius) and Megachile apicalis Spinola (Hymenoptera, Megachilidae). J. Kansas Entomol. Soc. 67, 53-72

Vit, P., Pulcini, P. (1996) Diastase and invertase activities in Meliponini and Trigonini honeys from Venezuala. J. Apic. Res. 35, 57-62

Wightman, J.A., Rogers, V.M. (1978) Growth, energy and nitrogen budgets and efficiencies of the growing larvae of Megachile pacifica (Hymenoptera: Megachilidae). Oecologia 36, 245-257 